\title{
Nornicotine impairs endothelial cell-cell adherens junction complexes in the EA.hy926 cell line via structural reorganization of $\mathrm{F}$-actin
}

\author{
Maciej Gagat ${ }^{1}$, Dariusz Grzanka ${ }^{2}$, Magdalena Izdebska ${ }^{1}$, Ewa Maczynska ${ }^{1}$, Alina Grzanka ${ }^{1}$ \\ ${ }^{1}$ Department of Histology and Embryology, Nicolaus Copernicus University in Torun, Collegium \\ Medicum in Bydgoszcz, Bydgoszcz, Poland \\ ${ }^{2}$ Department and Clinic of Dermatology, Sexually Transmitted Diseases, and Immunodermatology, \\ Nicolaus Copernicus University in Torun, Collegium Medicum in Bydgoszcz, Bydgoszcz, Poland
}

\begin{abstract}
The aim of the study was to estimate the effect of nornicotine on endothelial EA.hy926 cells in the context of its impact on cell-cell junctions. The objective of the study was to determine the relationship between junctional proteins and F-actin after treating the cells with nornicotine. After $24 \mathrm{~h}$ of cell exposure to $0.08,0.12$, and $0.16 \mathrm{ng} / \mathrm{mL}$ nornicotine, analysis was performed of cell death, cell migration, ultrastructure, and colocalization of beta-catenin/F-actin and zonula occludens (ZO)-1/F-actin. Our study did not reveal any alterations in EA.hy926 cell line survival following treatment with nornicotine. However, nornicotine exerted disparate effects on cell migration and led to changes in both the ultrastructure and organization of cell-cell junctional complexes and F-actin. Moreover, the cell migration observed in the experiments performed in the present work negatively correlated with the number of Weibel-Palade bodies seen through transmission electron microscopy (TEM). Moreover, the mechanism of cell migration promotion was VEGF-independent, and the decrease in the number of Weibel-Palade bodies resulted from nornicotine-induced F-actin depolymerization. In conclusion, the present study demonstrated that low concentrations of nornicotine do not affect cell survival, but promote cell movement and impair adherens junctions through changes in F-actin organization. Our results indicate for the first time the effect of nornicotine on endothelial EA.hy926 cells and suggest that nornicotine may induce transmigration pathways and, consequently, facilitate the transendothelial migration of monocytes associated with atherosclerosis. (Folia Histochemica et Cytobiologica 2013, Vol. 51, No. 3, 179-192)
\end{abstract}

Key words: endothelial cells, adherens junctions, tight junctions, F-actin, beta-catenin, zo-1, TEM

\section{Introduction}

The actin cytoskeleton is a very dynamic structure that plays an important role in many physiological and pathological processes. Since the identification of actin in nonmuscle cells, it is known that the mechanical behavior of the filamentous actin cytoskeleton (F-actin) regulates cellular shape changes and is also involved in cell migration, in which the precisely coordinated

Correspondence address: A. Grzanka, Department of Histology and Embryology, Nicolaus Copernicus University in Torun, Collegium Medicum in Bydgoszcz; Karlowicza St. 24, 85-092 Bydgoszcz, Poland; tel.: +48 5258537 25;

fax: +48 525853734 ; e-mail: agrzanka@cm.umk.pl polymerization of microfilaments, anchored to the plasma membrane, have an impact on the formation of plasma membrane protrusions and cell movement [1]. Furthermore, the maintenance of cell shape and cell polarity is very important in the formation of cell-cell junctions. It has been demonstrated that, through the interoperability of junctional actin and F-actin thin bundles, overall morphological changes lead to the development of a polarized epithelial cell [2].

Endothelial cells, similarly to epithelial cells, have specialized junctional regions, classified as adherens junctions (AJs) and tight junctions (TJs). TJs in the endothelium are intermixed with AJs along the intercellular cleft, but are not concentrated on the apical 
side of the cleft, as has been reported in epithelial cells [3]. It has been shown by many authors that the actin cytoskeleton is important for intercellular adhesion, being required not only for the stabilization of the junctions but also for the dynamic regulation of the opening and closing of cell-cell junctions [4-6]. The adhesion proteins involved in cell-cell junctional complexes may interact with cytoskeletal and signaling proteins, which allows the anchoring of the adhesion proteins to F-actin and the transfer of intracellular signals inside the cell [7-10]. It is also known that there are the molecular linkages between cadherins and F-actin in AJs; however, the structural organization and specific role of the actin cytoskeleton at adherens junctions still remains unknown, particularly for endothelial cells $[4-6,11]$. It has also been suggested that the transmigration of monocytes through circular openings is limited by F-actin and partially by alpha-catenin, resulting in monocyte accumulation in atherosclerotic plaques [12-13].

Atherosclerosis is a chronic disease that affects the arteries and may result in heart disease and myocardial infarction. Atherosclerosis is caused by arterial injuries that result from mechanical and environmental factors, such as diabetes, tobacco smoking, dyslipoproteinemia, and stress, and leads to endothelial dysfunction [14]. Cigarette smoking is one of the greatest risk factors for atherosclerosis. Cigarette smoke contains more than 4000 different chemicals, most of which are generated during the burning process in the cigarette and then inhaled by the smoker [15-17]. Hydrophobic compounds precipitate in the oral cavity and, after being swallowed, reach the digestive system. Inhaled compounds are precipitated on the surfaces of the respiratory tract. Since hydrophobic agents, such as polycyclic aromatic hydrocarbons (PAHs), can diffuse across cellular membranes and cell layers, the precipitated chemicals can penetrate the mucosal linings and reach the circulation, and consequently all organs of the body. The volatile fraction reaches the alveoli and diffuses directly across the lung-blood barrier. After entering the circulation, the chemicals from the smoke enter the biochemical and cellular transport systems, or else remain dissolved in serum [16-17]. Given the extremely high number of toxic substances, the effects of most of them on endothelial cells have not yet been established. However, it has been verified by in vitro and in vivo studies that the harmful effects of tobacco smoke involve the induction of oxidative stress [18-19].

The four major alkaloids produced in Nicotiana tabacum are nicotine, nornicotine, anabasine, and anatabine. Nicotine is the predominant alkaloid, representing $90-95 \%$ of the total alkaloid content, whereas the remaining three alkaloids account for $5-10 \%$ of the alkaloid pool [20]. Nornicotine levels are highest in cigar tobacco, anatabine levels are lowest in chewing tobacco and oral snuff, and anabasine levels are lowest in chewing tobacco [21]. In the literature, there is much evidence of the different effects of nicotine on endothelial cells, including up-regulation of VCAM-1, stimulation of cell migration, acceleration of wound repair, increases in sFlt-1 release, and impairment of cell-cell integrity [22-25]. However, knowledge of nicotine metabolites - especially in conjugation with cell-cell junctions - is poor. In the present study, nornicotine, a metabolite of nicotine, was used. The formation of nornicotine, a secondary tobacco alkaloid, from nicotine has been shown to be mediated by the cytochrome $\mathrm{P} 450$ system, in the process of the N-demethylation of nicotine [20, 26-28]. Moreover, it contributes to the neuropharmacological effects of nicotine and tobacco use and there is no evidence regarding its effect on endothelial cells [28].

The aim of the present study was to estimate the effect of nornicotine on the endothelial EA.hy926 cells in the context of its impact on cell-cell junctions. The authors have focused on finding the relationship between the junctional proteins and F-actin subsequent to the treatment of cells with nornicotine.

\section{Material and methods}

Cell culture and treatment. The immortalized human endothelial EA.hy926 cells (ATCC, CRL-2922) were cultured in monolayers at $37^{\circ} \mathrm{C}$ in a humidified $\mathrm{CO}_{2}$ incubator $\left(5 \% \mathrm{CO}_{2}\right)$ in DMEM (Gibco, Life Technologies), with the addition of $10 \%$ fetal bovine serum (FBS; Gibco, Life Technologies) and $50 \mu \mathrm{g} / \mathrm{mL}$ gentamycin (Sigma-Aldrich). The cells, grown in 6-well plates (Falcon, Becton Dickinson), were treated with $0.08,0.12$, and $0.16 \mathrm{ng} / \mathrm{mL}( \pm)$-nornicotine (Sigma -Aldrich) for $24 \mathrm{~h}$. The control cells were grown under the same conditions, but without the addition of nornicotine. Given the lack of objective information in the literature about nornicotine concentrations in the plasma of smokers and the aim of the present study, the chosen concentrations of nornicotine were selected to exert changes in cell-cell adhesion, rather than to affect cell survival.

Cell death analysis. The analysis of cell death was performed using a Tali Image-based cytometer (Invitrogen, Life Technologies) and Tali Apoptosis Kit (Invitrogen, Life Technologies) according to manufacturer's instructions. Briefly, after trypsinization of cells cultured for 24 hours in the presence or absence of $0.08,0.12$, or $0.16 \mathrm{ng} / \mathrm{mL}$ nornicotine, the suspension cells were centrifuged at $300 \times \mathrm{g}$ and resuspended in Annexin binding buffer at a concentration of approximately $5 \times 10^{5}$ to $5 \times 10^{6}$. Next, $5 \mu \mathrm{L}$ of Annexin $\mathrm{V}$ 
Alexa Fluor 488 was added to each $100 \mu \mathrm{L}$ of sample, mixed, and incubated at room temperature in the dark for $20 \mathrm{~min}$. The cells were then centrifuged and resuspended in $100 \mu \mathrm{L}$ of Annexin binding buffer. After the addition of $1 \mu \mathrm{L}$ of Propidium Iodide to each sample, the cells were incubated at room temperature in the dark for $3 \mathrm{~min} .25 \mu \mathrm{L}$ of stained cells were loaded into a Tali Cellular Analysis Slide (Invitrogen, Life Technologies). The data were analyzed using FCS Express Research Edition software (v. 4.03; De Novo Software) on the assumption that the viable cells would be both Annexin V Alexa Fluor 488-negative and Propidium Iodide-negative cells; cells that are in early apoptosis are Annexin V Alexa Fluor 488-positive and Propidium Iodidenegative; cells that are in late apoptosis are both Annexin V Alexa Fluor 488 and Propidium Iodide-positive; whereas necrotic cells are Annexin V Alexa Fluor 488-negative and Propidium Iodide-positive.

In vitro scratch wound healing assay. The EA.hy926 cells were seeded into a 6-well plate (Falcon, Becton Dickinson) and grown to confluency. The cell monolayer was then subjected to a mechanical scratch-wound induced using a $200 \mu \mathrm{L}$ sterile pipette tip. The cells were then cultured for additional period of 24 hours in the presence or absence of $0.08,0.12$, or $0.16 \mathrm{ng} / \mathrm{mL}$ nornicotine. Cells in the injury area were visualized under phase-contrast optics $(10 \times \mathrm{ob}-$ jective) using a TE100-U inverted microscope (Nikon), and photographed using a DS-5Mc-U1 CCD camera (Nikon) and NIS-Elements software (Ver3.30; Nikon). The wound area was measured using ImageJ (Ver1.45s; public domain) at 0 , $3,6,12$, and $24 \mathrm{~h}$ after treatment with nornicotine.

Transmission electron microscopy. For ultrastructural analysis, the EA.hy926 cells, cultured for 24 hours in the presence or absence of $0.08,0.12$, or $0.16 \mathrm{ng} / \mathrm{mL}$ nornicotine, were fixed for $30 \mathrm{~min}$ at room temperature with $3.6 \%$ glutaraldehyde, and then moved to $0.1 \mathrm{M}$ cacodylate buffer ( $\mathrm{pH} 7.4$ ). Following postfixing with $1 \%$ osmium tetroxide in cacodylate buffer for $60 \mathrm{~min}$, the studied material was dehydrated through a graded series of alcohols and embedded in Epon 812 (Roth). After resin polymerization $\left(24 \mathrm{~h}\right.$ at $37^{\circ} \mathrm{C}$ and $120 \mathrm{~h}$ at $65^{\circ} \mathrm{C}$ ), the parts of the material selected from the semithin sections were cut into ultrathin sections using a Reichert Om-U3 ultramicrotome (Leica) and counterstained with uranyl acetate. The prepared material was examined using a JEM 100 CX electron microscope (Jeol) operating at $80 \mathrm{kV}$.

Laser-scanning confocal microscopy. The EA.hy926 cells were seeded into 6-well plates (Falcon, BD) and grown on sterile glass coverslips. The cells were then cultured for 24 hours in the presence or absence of $0.08,0.12$, or $0.16 \mathrm{ng} / \mathrm{mL}$ nornicotine, fixed with $4 \%$ paraformaldehyde in $\mathrm{PBS}(\mathrm{pH}$ 7.4 for $15 \mathrm{~min}$ at room temperature), blocked in $1 \%(\mathrm{w} / \mathrm{v})$ BSA/PBS (bovine serum albumin in phosphate buffered saline), and then double-stained for junctional proteins and F-actin using antibodies and phalloidin conjugates in the following arrangement: (i) rabbit anti-beta-catenin (Sigma-Aldrich), anti-rabbit antibody-Alexa Fluor 555 (Invitrogen, Life Technologies), phalloidin-Alexa Fluor 488 (Molecular Probes, Life Technologies); (ii) mouse anti-ZO-1 (Invitrogen, Life Technologies), anti-mouse antibody-Alexa Fluor 488 (Invitrogen, Life Technologies), phalloidin-TRITC (Sigma-Aldrich). Cell nuclei were stained with DAPI (Sigma-Aldrich). The slides were mounted in Aqua-Poly/ /Mount (Polysciences) and examined using a C1 laser-scanning confocal microscopy system (Nikon) with a $100 \times$ oil immersion objective. The images from triple labeling were simultaneously collected at the brightest signals of junctional protein using Nikon EZ-C1 software (Ver3.80; Nikon). All images of the same junctional protein were acquired and generated using laser power, pixel dwell, and gain.

Measurement of fluorescence intensity. The measurement of fluorescence intensity of each junctional protein and F-actin in the EA.hy926 cells, with and without exposure to 0.08 , 0.12 , or $0.16 \mathrm{ng} / \mathrm{mL}$ nornicotine, was performed on confocal images acquired at the brightest signals of junctional protein at the cell edges. The fluorescence intensity measurement of beta-catenin, ZO-1, and F-actin was carried out on whole cells and on cell-cell interaction areas using Nikon EZ-C1 software (Ver3.90, Gold; Nikon). The relative fluorescence values of junctional proteins and of the F-actin colocalized with them were calculated by dividing the fluorescence intensity values measured in cell-cell interaction areas by the medians of the fluorescence intensity measured in the cell-cell interaction areas of the control cells.

Statistical analysis. The data are shown as means \pm SEM. A two-way ANOVA analysis was performed for the wound healing data, and a two-tailed unpaired $t$-test was utilized to analyze the statistical significance of the differences between the percentage of wound area in EA.hy 926 cultured with and without exposure to $0.08,0.12$, or $0.16 \mathrm{ng} / \mathrm{mL}$ nornicotine. Statistical comparisons between the two groups of fluorescence intensity or cell death data were performed using a two-tailed Mann-Whitney $U$-test. Differences between groups were considered significant when $\mathrm{P}<0.05$. GraphPad Prism 5.0 (GraphPad Software) was used for the statistical analyses.

\section{Results}

\section{Effect of nornicotine on EA.hy926 cell death}

The analysis of cell death was performed using a Tali Image-based cytometer following Annexin V Alexa Fluor 488 and Propidium Iodide double staining. In the EA.hy926 cells treated with nornicotine at concentrations of $0.08,0.12$, and $0.16 \mathrm{ng} / \mathrm{mL}$, no 


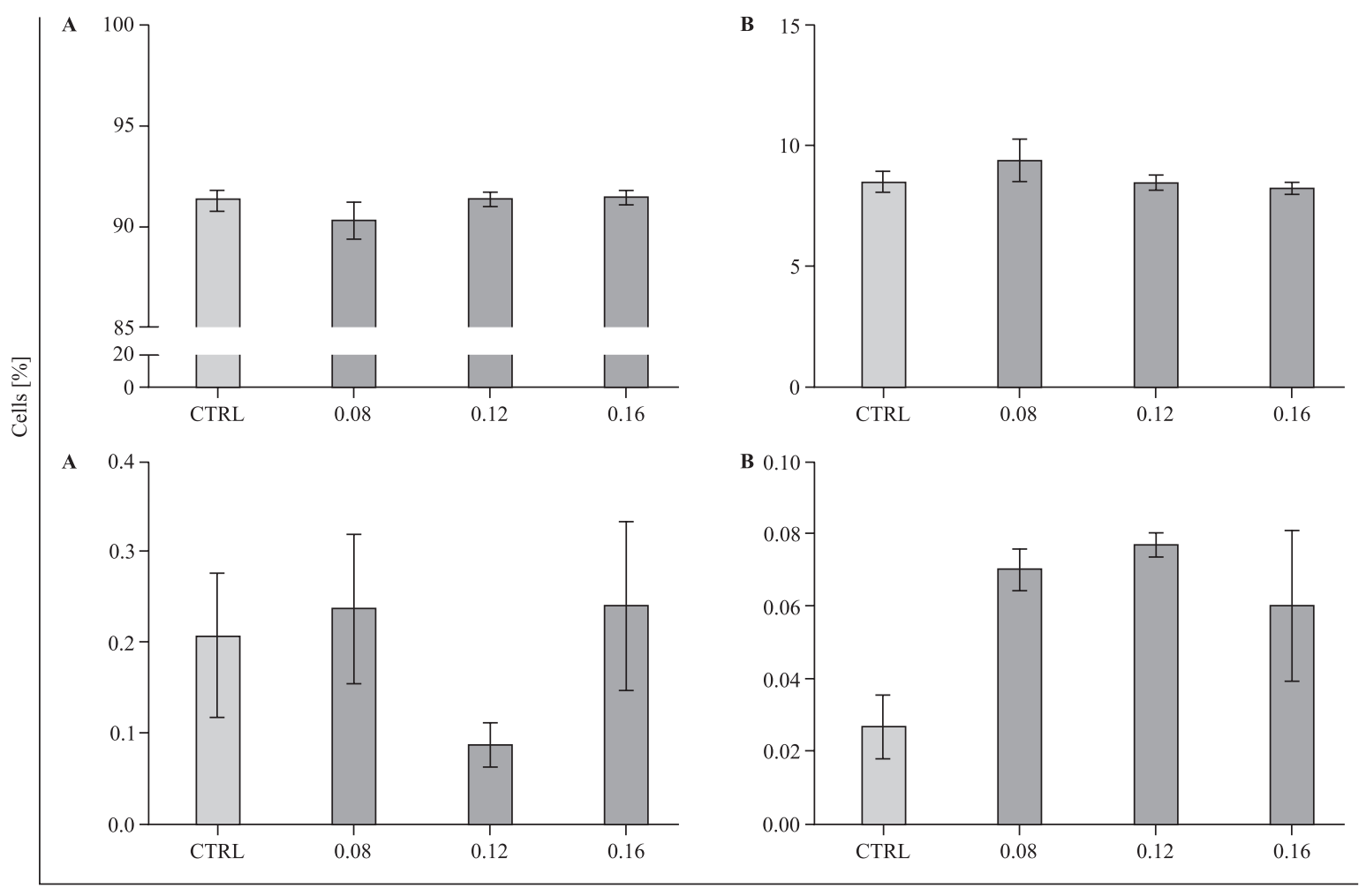

Nornicotine concentration $[\mathrm{ng} / \mathrm{ml}]$

Figure 1. The effect of nornicotine on the induction of cell death. EA.hy926 cells were treated with $0.08,0.12$, and $0.16 \mathrm{ng} / \mathrm{mL}$ nornicotine for $24 \mathrm{~h}$ and double-stained with Annexin V Alexa Fluor 488 and Propidium Iodide. Analysis was performed using an image-based cytometer. (A) Percentage of live cells; (B) Percentage of early apoptotic cells; (C) Percentage of late apoptotic cells; (D) Percentage of necrotic cells. CTRL - control

statistically significant differences in the percentage of live, early-apoptotic, late-apoptotic, and necrotic cells were seen, compared to the controls. Similarly, the comparison of the results obtained for cells treated with all doses of nornicotine also did not reveal statistically significant differences in the percentage of live, early-apoptotic, late-apoptotic, and necrotic cells (Figure $1 \mathrm{~A}-\mathrm{D}$ ).

\section{Effect of nornicotine on EA.hy926 cell migration}

Cell mobility was assessed with a wound healing assay. The wound area was photographed under phase-contrast optics and measured $0,3,6,12$, and $24 \mathrm{~h}$ after the treatment of the cells with $0.08,0.12$, or $0.16 \mathrm{ng} /$ $/ \mathrm{mL}$ nornicotine.

The results showed that all doses of nornicotine increased the migratory potential of the EA.hy926 cells in a statistically significant way, compared with the control. After treatment of the cells with nornicotine at concentrations of 0.08 and $0.16 \mathrm{ng} / \mathrm{mL}$, the wound area was almost completely repaired following $12 \mathrm{~h}$. In the case of the control and the cells treated with $0.12 \mathrm{ng} / \mathrm{mL}$ nornicotine, the wound borders were still clearly detectable $24 \mathrm{~h}$ after wound formation. Moreover, comparison of wound repair results using two-way ANOVA indicate that the time, considered as the duration of the experiment, played a crucial role in the wound healing assay (interaction: $6.73 \%$ of the total variance, $\mathrm{P}<0.0001$; column factor: $10.36 \%$ of the total variance, $\mathrm{P}<0.0001$; and time: $82.52 \%$ of the total variance, $\mathrm{P}<0.0001$ ) (Figure 2).

\section{Effect of nornicotine on EA.hy926 cell ultrastructure}

Ultrastructure analysis of the EA.hy926 cells, cultured with and without exposure to $0.08,0.12$, or $0.16 \mathrm{ng} / \mathrm{mL}$ nornicotine, was performed using a transmission electron microscope (TEM), which revealed the relation between of the reorganization of the filopodia structure and the increased concentration of nornicotine. In the control, the cells were characterized by the appearance of branched cell processes (Figure $3 \mathrm{~A}$ ). After treatment of the cells with 0.08 and $0.12 \mathrm{ng} / \mathrm{mL}$ nornicotine, both their organization and number was decreased (Figure 3 B-C). The filopodia in cells 


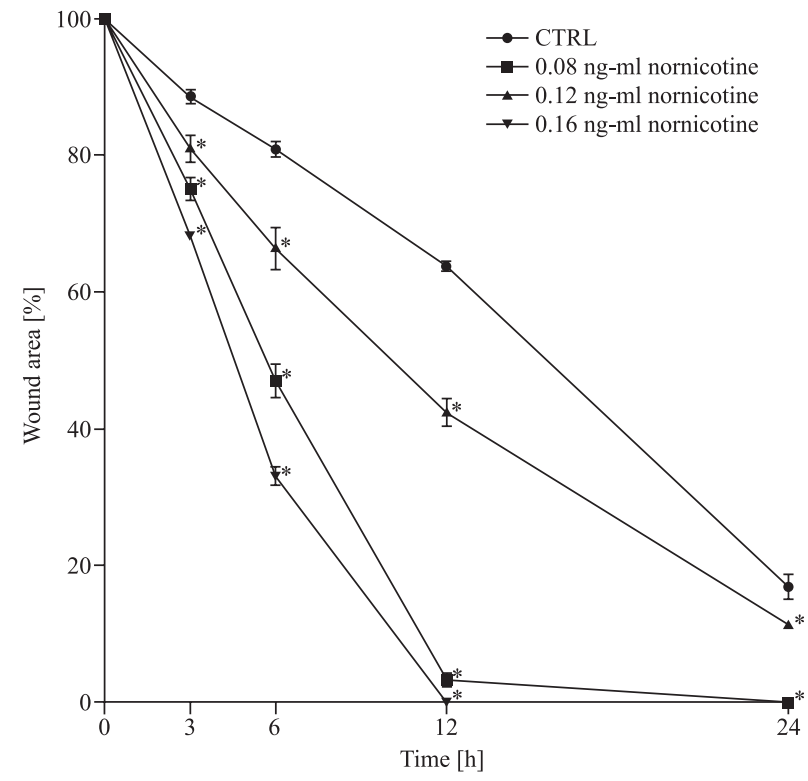

Figure 2. Effect of nornicotine on cell mobility. EA.hy926 cells were grown to confluency, subjected to mechanical scratch-wound induction, and treated with $0.08,0.12$, and $0.16 \mathrm{ng} / \mathrm{mL}$ nornicotine for $24 \mathrm{~h}$. The wound area was photographed under phase-contrast optics and measured at $0,3,6,12$, and $24 \mathrm{~h}$ after treatment of the cells with nornicotine. *Statistically significant differences between groups; $\mathrm{P}<0.05$; unpaired $t$-test. CTRL - control treated with $0.16 \mathrm{ng} / \mathrm{mL}$ nornicotine were long, thin, and reduced in number (Figure $3 \mathrm{D}$ ), confirming the observation obtained during microscopic analysis of migratory potential. Ultrastructural analysis also revealed irregularly arranged, oval, electron-dense structures, similar to Weibel-Palade bodies, whose number was similar to that of the control after treatment of the cells with $0.12 \mathrm{ng} / \mathrm{mL}$ nornicotine (Figure $3 \mathrm{C}$ ) and reduced after exposure of the cells to 0.08 and $0.16 \mathrm{ng} / \mathrm{mL}$ nornicotine (Figure $3 \mathrm{~B}, \mathrm{D}$ ). TEM also revealed two types of vacuoles following treatment of the cells with nornicotine. The first type contained fine fibrillar material and the second type contained mostly amorphous material (Figure $3 \mathrm{~B}-\mathrm{D}$ ).

\section{Fluorescent staining of beta-catenin and F-actin in EA.hy926 cells treated with nornicotine}

The effect of nornicotine on the fluorescent staining of beta-catenin and F-actin in EA.hy926 cells was investigated using a laser scanning confocal microscope. The images were acquired in confocal mode in the focal plane of junctional beta-catenin. Fluorescent double staining of beta-catenin and F-actin revealed a decrease in fluorescent labeling of both beta-catenin and F-actin following treatment with $0.08,0.12$, and

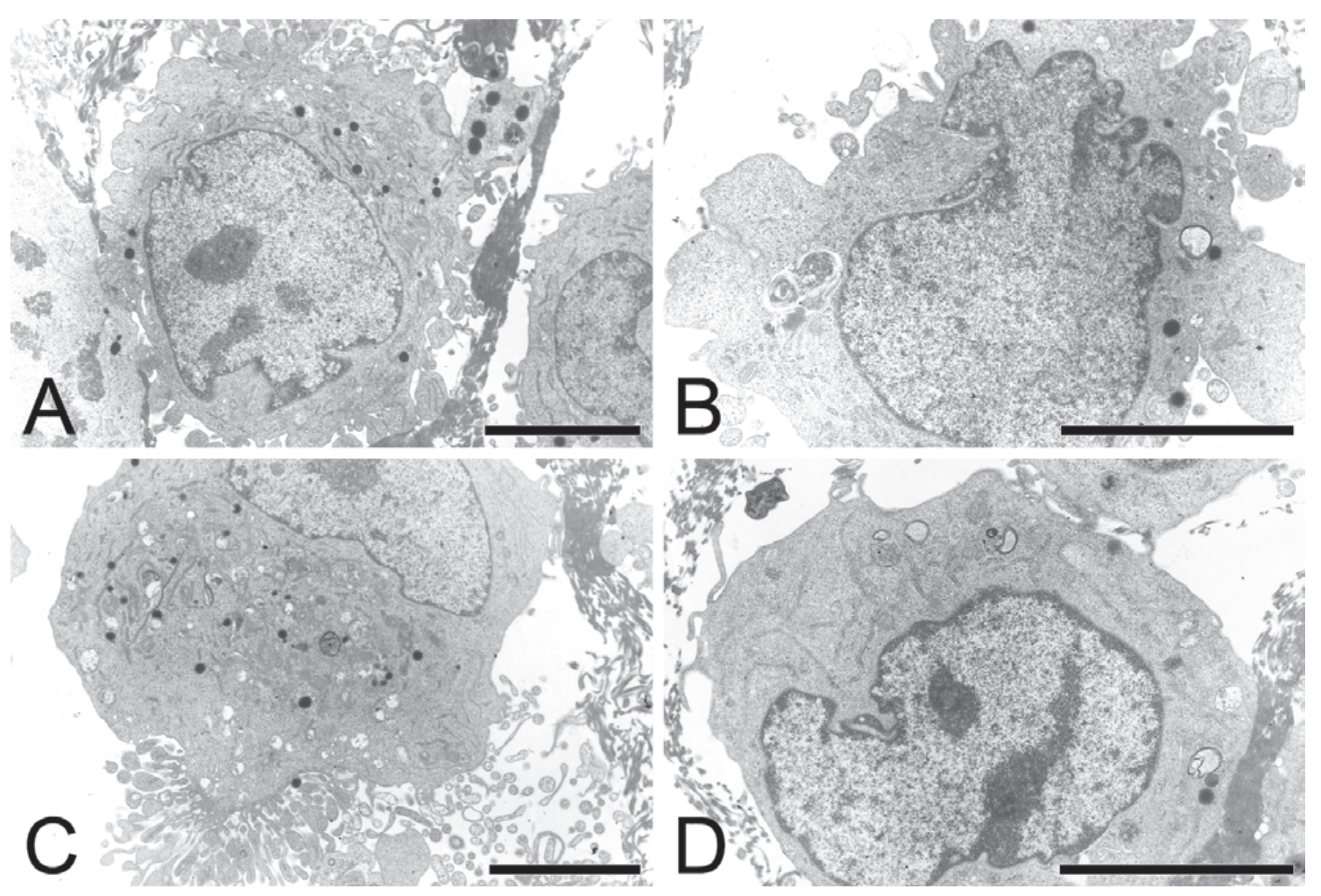

Figure 3. Effect of nornicotine on the induction of cell death. EA.hy 926 cells were treated with $0.08,0.12$, and $0.16 \mathrm{ng} / \mathrm{mL}$ nornicotine for $24 \mathrm{~h}$ and examined by transmission electron microscopy. (A) Control EA.hy926 cells; (B) EA.hy926 cells treated with $0.08 \mathrm{ng} / \mathrm{mL}$ nornicotine; (C) EA.hy926 cells treated with $0.12 \mathrm{ng} / \mathrm{mL}$ nornicotine; (D) EA.hy926 cells treated with $0.16 \mathrm{ng} / \mathrm{mL}$ nornicotine. Bar $=5 \mu \mathrm{m}$ 


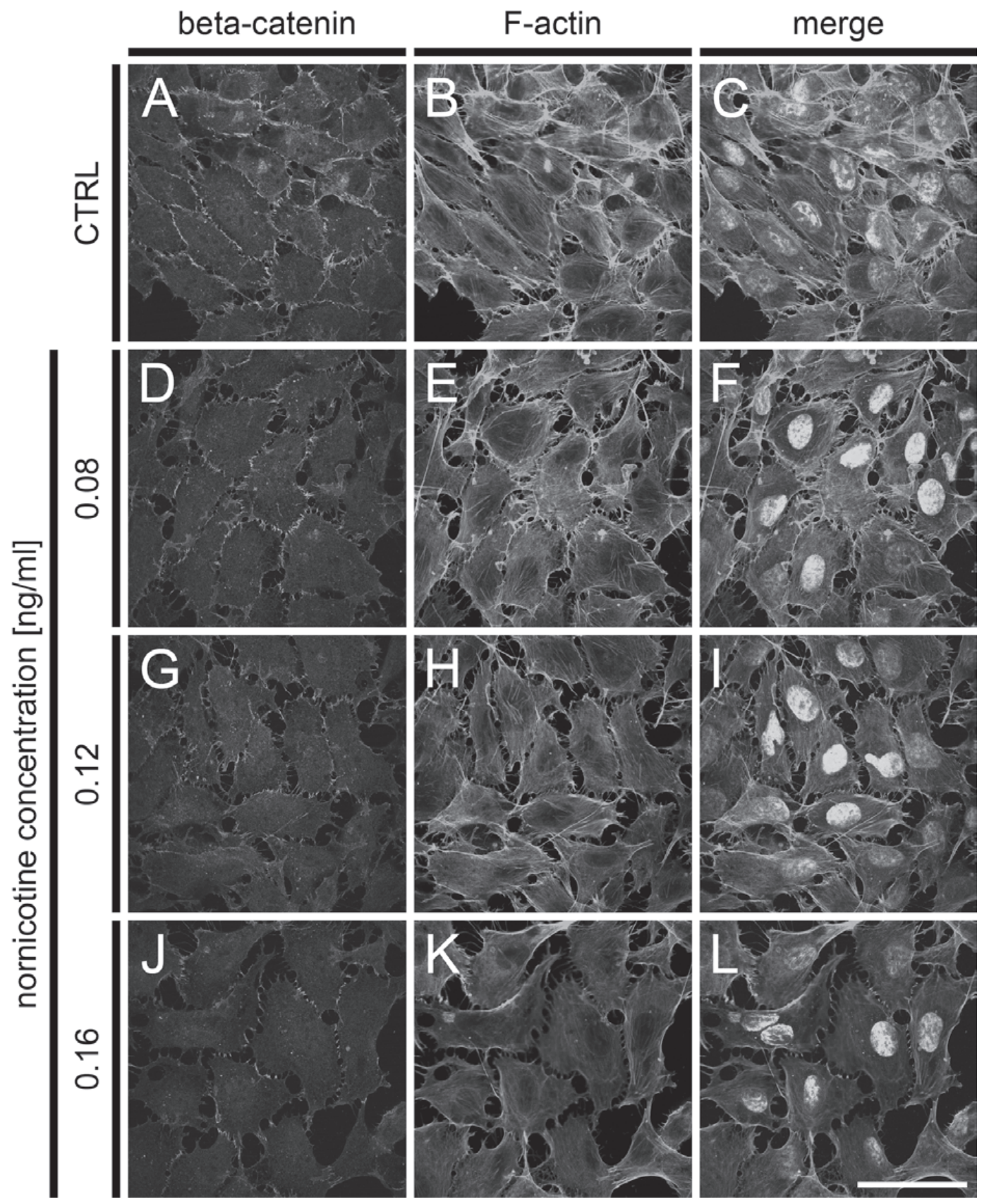

Figure 4. Effect of nornicotine on colocalization of beta-catenin and F-actin. EA.hy926 cells were treated with 0.08 , 0.12, and $0.16 \mathrm{ng} / \mathrm{mL}$ nornicotine for $24 \mathrm{~h}$ and examined by confocal microscopy. (A-C) Control EA.hy926 cells; (D-F) EA.hy926 cells treated with $0.08 \mathrm{ng} / \mathrm{mL}$ nornicotine. (G-I) EA.hy926 cells treated with $0.12 \mathrm{ng} / \mathrm{mL}$ nornicotine; (J-L) EA.hy926 cells treated with $0.16 \mathrm{ng} / \mathrm{mL}$ nornicotine. (A, D, G, J) Beta-catenin, (B, E, H, K) F-actin, (C, F, I, L) merged. Bar $=50 \mu \mathrm{m}$. CTRL - control

$0.16 \mathrm{ng} / \mathrm{mL}$ nornicotine, compared with the control (Figure $4 \mathrm{~A}-\mathrm{L}$ ). The weakest labeling of the analyzed protein and protein polymer was observed in cells treated with the highest dose of nornicotine (Figure 4 $\mathrm{J}-\mathrm{L}$ ). Moreover, following treatment of cells with 0.12 and $0.16 \mathrm{ng} / \mathrm{mL}$ nornicotine, an increase in extracellular space was noticed as a consequence of the loss of cell-cell contact (Figure 4 G-I, J-L). In line with the organization of F-actin, thin tension fibers were seen in control cells (Figure 4 B-C). Following the treatment of cells with all doses of nornicotine, stress fibers were formed. However, their fluorescence was decreased to that observed in control F-actin structures (Figure 4 E-F, H-I, K-L). 
The measurement of the fluorescence intensity of beta-catenin and F-actin in the EA.hy926 cells cultured with and without exposure to $0.08,0.12$, or $0.16 \mathrm{ng} / \mathrm{mL}$ nornicotine was performed on confocal images acquired in the focal plane of beta-catenin. The fluorescence intensity of both F-actin and betacatenin was measured in whole cells and in cell-cell interaction areas at the focal plane of beta-catenin.

The analysis of the fluorescence intensity of betacatenin measured in whole EA.hy926 cells showed a statistically significant decrease in comparison to the control $(\mathrm{P}=0.0026, \mathrm{P}=0.0391$, and $\mathrm{P}<0.0001$ for cells treated with $0.08,0.12$, and $0.16 \mathrm{ng} / \mathrm{mL}$ nornicotine, respectively). A statistically significant decrease in the fluorescence intensity of beta-catenin was also observed not only for cells treated with 0.08 and $0.16 \mathrm{ng} / \mathrm{mL}$ nornicotine $(\mathrm{P}<0.0001)$, but also for those treated with 0.12 and $0.16 \mathrm{ng} / \mathrm{mL}$ nornicotine $(\mathrm{P}<0.0001)$. The difference between cells treated with 0.08 and $0.12 \mathrm{ng} / \mathrm{mL}$ nornicotine was statistically insignificant $(\mathrm{P}=0.7319)$ (Figure 5A; Table 1$)$. A similar decrease in beta-catenin fluorescence, compared with the control, was observed after measurement of its intensity in cell-cell interaction areas $(\mathrm{P}<0.0001$ for cells treated with $0.08,0.12$, and $0.16 \mathrm{ng} / \mathrm{mL}$ nornicotine). However, the values of fluorescence intensity were in this case 2.30-2.63 times higher. The measurement of the fluorescence intensity of beta-catenin in cell-cell interaction areas also showed its statistically significant decrease from cells treated with nornicotine in concentration of 0.08 and $0.16 \mathrm{ng} / \mathrm{mL}(\mathrm{P}=0.0009)$ to those treated with 0.12 and $0.16 \mathrm{ng} / \mathrm{mL}$ nornicotine $(\mathrm{P}=0.0002)$. The difference between cells treated with 0.08 and $0.12 \mathrm{ng} / \mathrm{mL}$ nornicotine was statistically insignificant $(\mathrm{P}=0.6713)$ (Figure $5 \mathrm{~B}$, Table 1).

The analysis of fluorescence intensity of F-actin measured in whole EA.hy926 cells in the focal plane of junctional beta-catenin showed a dose-dependent statistically significant decrease in comparison with the control $(\mathrm{P}=0.0219, \mathrm{P}=0.0078$, and $\mathrm{P}<0.0001$ for cells treated with $0.08,0.12$, and $0.16 \mathrm{ng} / \mathrm{mL}$ nornicotine, respectively). Statistically significant decreases in the fluorescence intensity of F-actin were also observed between cells treated with nornicotine not only at concentrations of 0.08 and $0.16 \mathrm{ng} / \mathrm{mL}(\mathrm{P}<0.0001)$, but also at 0.12 and $0.16 \mathrm{ng} / \mathrm{mL}(\mathrm{P}<0.0001)$. The difference between cells treated with 0.08 and $0.12 \mathrm{ng} / \mathrm{mL}$ nornicotine was statistically insignificant $(\mathrm{P}=0.5590)$ (Figure $5 \mathrm{C}$, Table 1). A similar dose-dependent decrease in F-actin fluorescence, as compared with the control, was observed following measurement of its intensity in cell-cell interaction areas in the focal plane of junctional beta-catenin
$(\mathrm{P}=0.0161, \mathrm{P}=0.0006$, and $\mathrm{P}<0.0001$ for cells treated with $0.08,0.12$, and $0.16 \mathrm{ng} / \mathrm{mL}$ nornicotine, respectively). However, the values of fluorescence intensity were 1.58-1.69 times higher in this case. The measurement of the fluorescence intensity of F-actin in cell-cell interaction areas also showed a statistically significant decrease between cells treated with nornicotine at concentrations of 0.08 and $0.16 \mathrm{ng} / \mathrm{mL}$ $(\mathrm{P}<0.0001)$ and those treated at 0.12 and $0.16 \mathrm{ng} / \mathrm{mL}$ $(\mathrm{P}<0.0001)$. The difference between cells treated with 0.08 and with $0.12 \mathrm{ng} / \mathrm{mL}$ nornicotine dose was statistically insignificant $(\mathrm{P}=0.1977)$ (Figure $5 \mathrm{D}$, Table 1).

\section{Fluorescent staining of ZO-1 and F-actin in EA.hy926 cells treated with nornicotine}

The effect of nornicotine on the fluorescent staining of ZO-1 and F-actin in EA.hy926 cells was investigated using a laser scanning confocal microscope. The images were acquired in confocal mode in the focal plane of junctional ZO-1. Fluorescent double staining of ZO-1 and F-actin revealed a decrease in the fluorescence labeling of ZO-1 following treatment with $0.08,0.12$, and $0.16 \mathrm{ng} / \mathrm{mL}$ nornicotine, as compared with the control (Figure 6 A, C, D, F, G, I, J, L). The weakest labeling of the analyzed protein and protein polymer was observed in cells treated with the highest dose of nornicotine (Figure $6 \mathrm{~J}, \mathrm{~L}$ ), however, very close to that observed in cells cultured with 0.08 and $0.12 \mathrm{ng} / \mathrm{mL}$ nornicotine (Figure $6 \mathrm{D}$, F, G, I). Moreover, following treatment of cells with nornicotine, cell-cell contact was decreased (Figure 4 D-F, G-I, J-L). The fluorescence of F-actin acquired in the focal plane of the ZO-1 protein was different to that observed in the focal plane of beta-catenin. The fluorescence of F-actin in cells treated with $0.12 \mathrm{ng} / \mathrm{mL}$ nornicotine was only slightly lower than that of F-actin observed in the control cells (Figure $6 \mathrm{~B}-\mathrm{C}, \mathrm{H}-\mathrm{I}$ ). $\mathrm{F}$-actin fluorescence in the cells treated with 0.08 and $0.16 \mathrm{ng} / \mathrm{mL}$ nornicotine was decreased (Figure $6 \mathrm{E}-\mathrm{F}$, $\mathrm{K}-\mathrm{L}$ ). On account of the organization of F-actin, thin tension fibers were seen in control cells (Figure 6 B-C). Following treatment of cells with all doses of nornicotine, stress fibers were formed. However, their fluorescence decreased to that observed in the control F-actin structures (Figure 4 E-F, H-I, K-L).

The measurement of fluorescence intensity of ZO-1 and F-actin in the EA.hy926 cells cultured with and without exposure to $0.08,0.12$, or $0.16 \mathrm{ng} / \mathrm{mL}$ nornicotine was performed on confocal images acquired in the focal plane of ZO-1. The fluorescence intensity of both F-actin and ZO-1 was measured in whole cells and in cell-cell interaction areas, in the focal plane of ZO-1. 


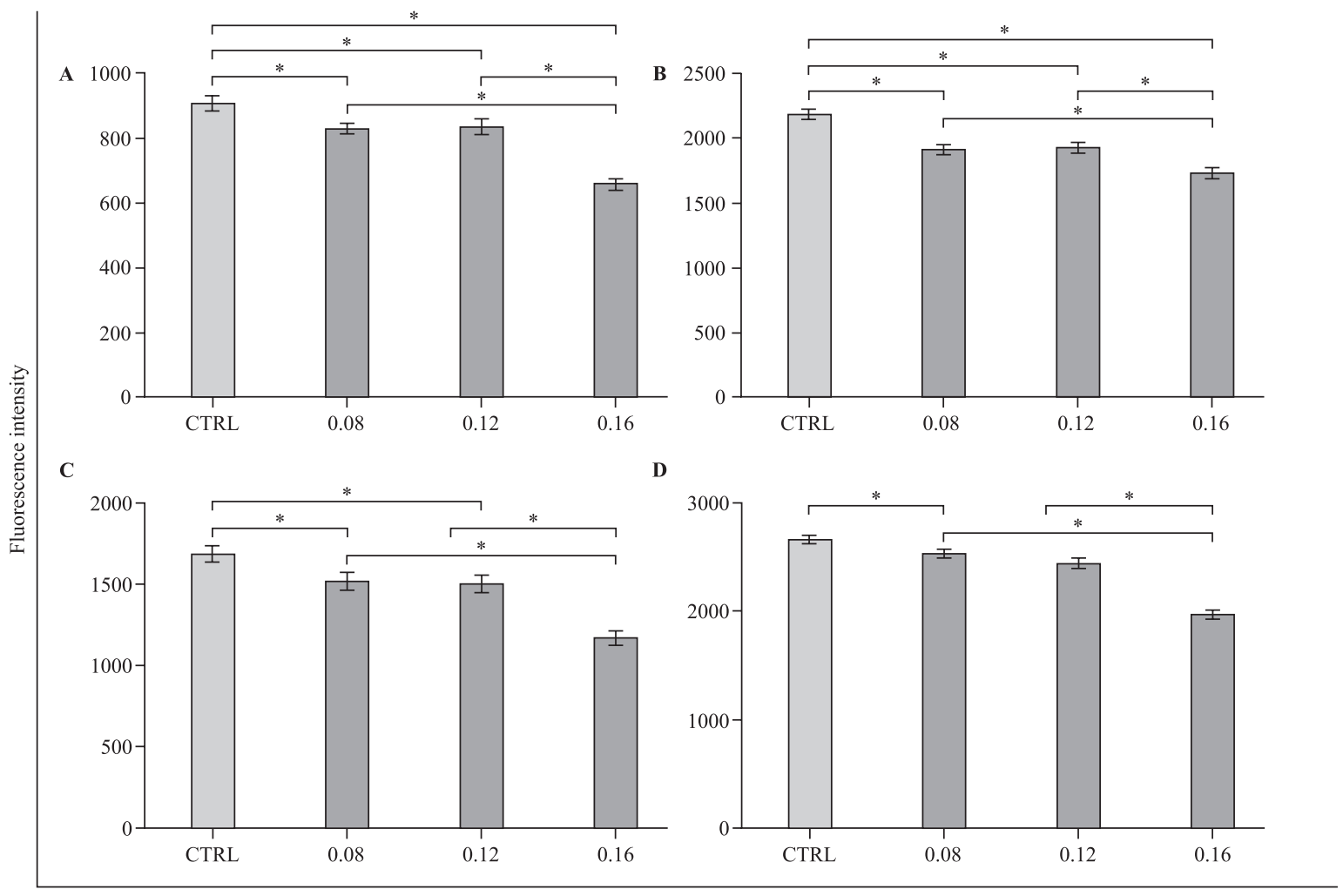

Nornicotine concentration $[\mathrm{ng} / \mathrm{ml}]$

Figure 5. Effect of nornicotine on the fluorescence intensity of beta-catenin and F-actin. EA.hy926 cells were treated with $0.08,0.12$, and $0.16 \mathrm{ng} / \mathrm{mL}$ nornicotine for $24 \mathrm{~h}$ and examined by confocal microscopy. Images were captured in the focal plane of junctional beta-catenin under a confocal microscope. The fluorescence intensity of the beta-catenin and F-actin was analyzed with confocal images for whole cells and cell-cell interaction areas. * Statistically significant differences; P $<0.05$; Mann-Whitney $U$-test. (A, B) Fluorescence intensity of beta-catenin measured in EA.hy926 cells treated with nornicotine; (C, D) Fluorescence intensity of F-actin measured in EA.hy926 cells treated with nornicotine. (A, C) Fluorescence intensity measured in whole cells. (B, D) Fluorescence intensity measured in cell-cell interaction areas. CTRL — control

Table 1. Mean fluorescence intensity values of beta-catenin and F-actin measured for whole cells and cell-cell interaction areas after treatment of EA.hy926 cells with nornicotine for $24 \mathrm{~h}$

\begin{tabular}{|l|l|c|c|c|c|}
\hline \multicolumn{2}{|l}{} & $\begin{array}{c}\text { Beta-catenin } \\
\text { whole cells }\end{array}$ & $\begin{array}{c}\text { Beta-catenin } \\
\text { cell-cell interaction } \\
\text { areas }\end{array}$ & $\begin{array}{c}\text { F-actin } \\
\text { whole cells }\end{array}$ & $\begin{array}{c}\text { F-actin } \\
\text { cell-cell interaction } \\
\text { areas }\end{array}$ \\
\hline \multirow{3}{*}{$\begin{array}{l}\text { Nornicotine concentration } \\
{[\mathrm{ng} / \mathrm{mL}]}\end{array}$} & CTRL & $907.03^{\mathrm{b}, \mathrm{c}, \mathrm{d}}$ & $2181.88^{\mathrm{b}, \mathrm{d}, \mathrm{d}}$ & $1684.76^{\mathrm{b}, \mathrm{c}, \mathrm{d}}$ & $2662.91^{\mathrm{b}, \mathrm{c}, \mathrm{d}}$ \\
\cline { 2 - 6 } & 0.08 & $828.55^{\mathrm{a}, \mathrm{d}}$ & $1910.55^{\mathrm{a}, \mathrm{d}}$ & $1518.45^{\mathrm{a}, \mathrm{d}}$ & $2533.03^{\mathrm{a}, \mathrm{d}}$ \\
\cline { 2 - 6 } & 0.12 & $833.48^{\mathrm{a}, \mathrm{d}}$ & $1926.25^{\mathrm{a}, \mathrm{d}}$ & $1502.70^{\mathrm{a}, \mathrm{d}}$ & $2443.81^{\mathrm{a}, \mathrm{d}}$ \\
\cline { 2 - 6 } & 0.16 & $658.73^{\mathrm{a}, \mathrm{b}, \mathrm{c}}$ & $1731.30^{\mathrm{a}, \mathrm{b}, \mathrm{c}}$ & $1169.63^{\mathrm{a}, \mathrm{b}, \mathrm{c}}$ & $1973.07^{\mathrm{a}, \mathrm{b}, \mathrm{c}}$ \\
\hline
\end{tabular}

${ }^{\mathrm{a}-\mathrm{d} d}$ statistically significant differences $\left(\mathrm{P}<0.05\right.$; Mann-Whitney $U$-test); ${ }^{\mathrm{a}}$ vs. CTRL; ${ }^{\mathrm{b}}$ vs. $0.08 \mathrm{ng} / \mathrm{mL}$ nornicotine; ${ }^{c} v s .0 .12 \mathrm{ng} / \mathrm{mL}$ nornicotine; ${ }^{d}$ vs. $0.16 \mathrm{ng} / \mathrm{mL}$ nornicotine. CTRL — control

Analysis of the fluorescence intensity of ZO-1 as measured in whole EA.hy926 cells showed a statistically significant decrease, compared with the control $(\mathrm{P}=0.0007, \mathrm{P}=0.0060$, and $\mathrm{P}<0.0001$ for cells treated with $0.08,0.12$, and $0.16 \mathrm{ng} / \mathrm{mL}$ nornicotine, respectively). Statistically significant decreases in the fluorescence intensity of beta-catenin were also noticed in cells treated with nornicotine in concentration of 0.12 and $0.16 \mathrm{ng} / \mathrm{mL}(\mathrm{P}=0.0012)$. The differences between cells treated with 0.08 and $0.12 \mathrm{ng} / \mathrm{mL}$ and those treated with 0.08 and $0.16 \mathrm{ng} / \mathrm{mL}$ nornicotine were statistically insignificant $(\mathrm{P}=0.2750$ and 


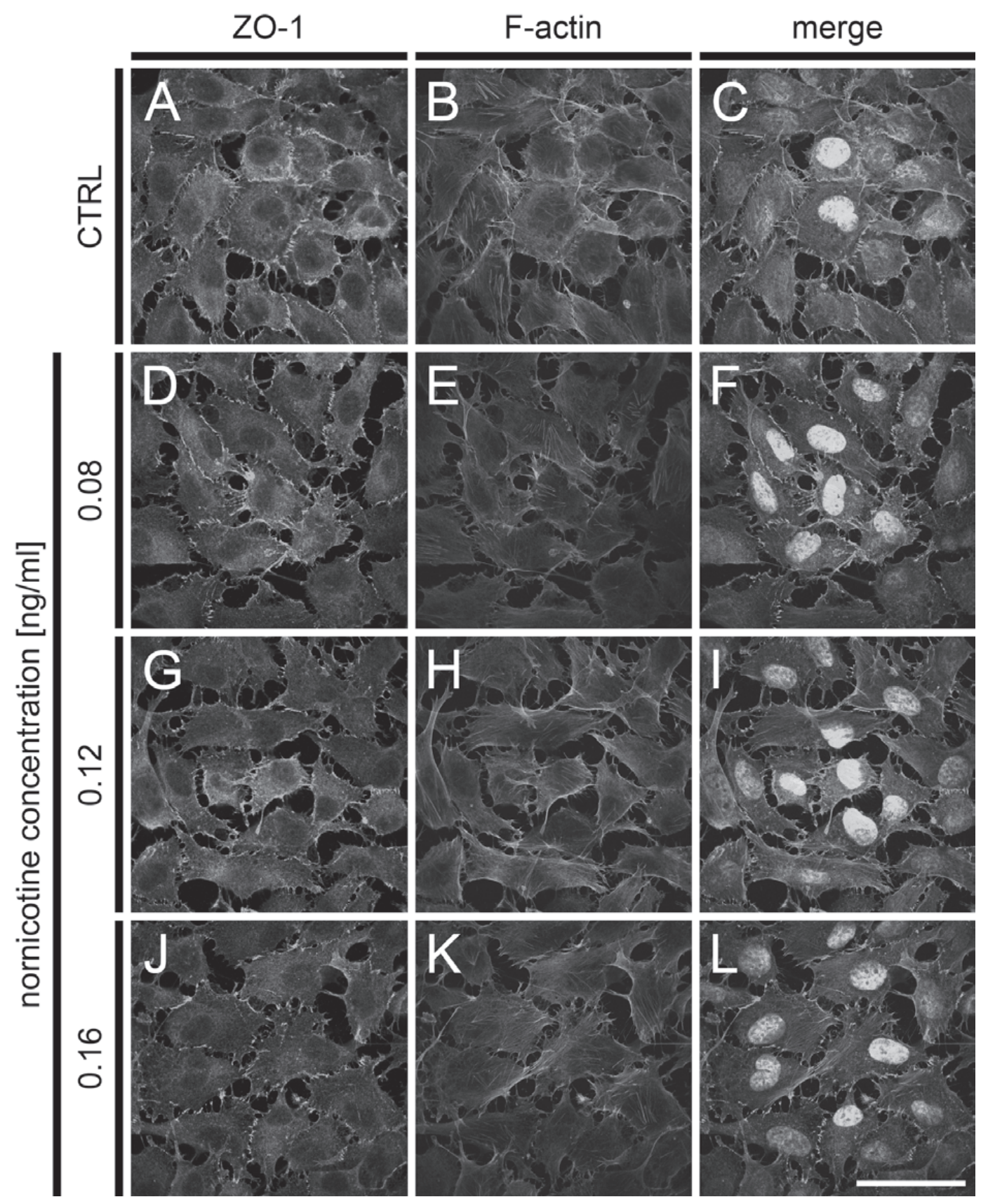

Figure 6. Effect of nornicotine on colocalization of ZO-1 and F-actin. EA.hy926 cells were treated with 0.08, 0.12, and $0.16 \mathrm{ng} / \mathrm{mL}$ nornicotine for $24 \mathrm{~h}$ and examined by confocal microscopy. (A-C) Control EA.hy926 cells; (D-F) EA.hy926 cells treated with $0.08 \mathrm{ng} / \mathrm{mL}$ nornicotine; (G-I) EA.hy926 cells treated with $0.12 \mathrm{ng} / \mathrm{mL}$ nornicotine; (J-L) EA.hy926 cells treated with $0.16 \mathrm{ng} / \mathrm{mL}$ nornicotine. (A, D, G, J) ZO-1, (B, E, H, K) F-actin, (C, F, I, L) merged. Bar $=50 \mu \mathrm{m}$. CTRL - control

$\mathrm{P}=0.0603$, respectively) (Figure $7 \mathrm{~A}$, Table 2). A similar decrease in ZO-1 fluorescence, as compared with the control, was observed following measurement of its intensity in cell-cell interaction areas $(\mathrm{P}<0.0001$ for cells treated with $0.08,0.12$, and $0.16 \mathrm{ng} / \mathrm{mL}$ nornicotine). However, the values of fluorescence intensity were 2.30-2.65 times higher.
Additionally, the differences between cells treated with all nornicotine doses were statistically insignificant $(\mathrm{P}=0.5892$ in the comparison of 0.08 and $0.12 \mathrm{ng} / \mathrm{mL}$ nornicotine, $\mathrm{P}=0.0509$ in the comparison of 0.08 and $0.16 \mathrm{ng} / \mathrm{mL}$ nornicotine, and $\mathrm{P}=0.1201$ in the comparison of 0.12 and $0.16 \mathrm{ng} / \mathrm{mL}$ nornicotine) (Figure 7 B, Table 2). 


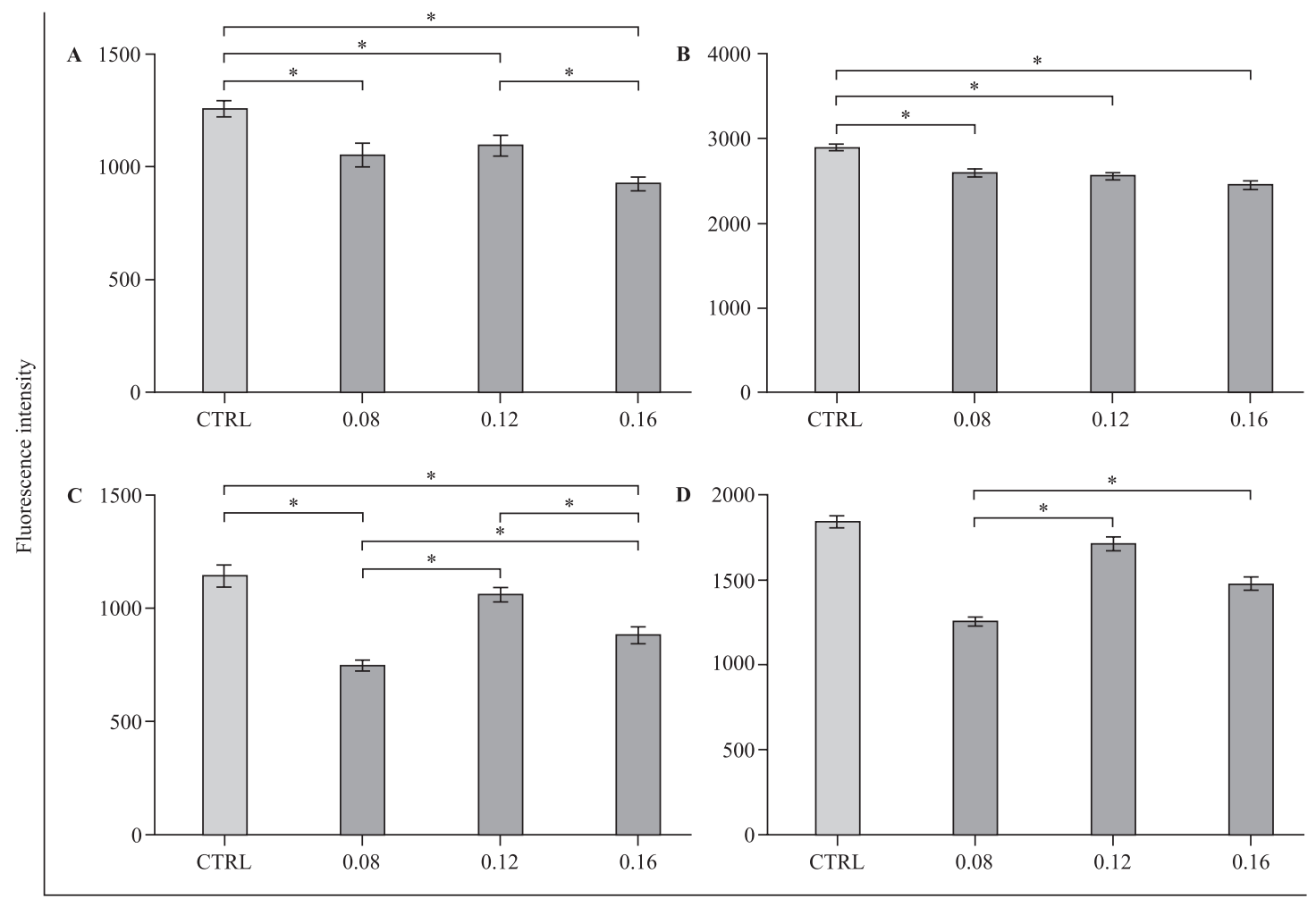

Nornicotine concentration $[\mathrm{ng} / \mathrm{ml}]$

Figure 7. Effect of nornicotine on the fluorescence intensity of ZO-1 and F-actin. EA.hy926 cells were treated with 0.08 , 0.12 , and $0.16 \mathrm{ng} / \mathrm{mL}$ nornicotine for $24 \mathrm{~h}$ and examined by confocal microscopy. Images were captured in the focal plane of junctional ZO-1 under a confocal microscope. The analysis of fluorescence intensity of ZO-1 and F-actin was performed on confocal images for whole cells and cell-cell interaction areas. *Statistically significant differences; $\mathrm{P}<0.05$; Mann-Whitney $U$-test. (A, B) Fluorescence intensity of beta-catenin measured in EA.hy926 cells treated with nornicotine; (C, D) Fluorescence intensity of F-actin measured in EA.hy926 cells treated with nornicotine. (A, C) Fluorescence intensity measured in whole cells. (B, D) Fluorescence intensity measured in cell-cell interaction areas. CTRL - control

Table 2. Mean fluorescence intensity values of ZO-1 and F-actin measured in whole cells and cell-cell interaction areas after treatment of EA.hy926 cells with nornicotine for $24 \mathrm{~h}$

\begin{tabular}{|l|l|c|c|c|c|}
\hline \multicolumn{2}{|l|}{} & $\begin{array}{c}\text { ZO-1 } \\
\text { whole cells }\end{array}$ & $\begin{array}{c}\text { ZO-1 } \\
\text { cell-cell interaction } \\
\text { areas }\end{array}$ & $\begin{array}{c}\text { F-actin } \\
\text { whole cells }\end{array}$ & $\begin{array}{c}\text { F-actin } \\
\text { cell-cell interaction } \\
\text { areas }\end{array}$ \\
\hline \multirow{3}{*}{$\begin{array}{l}\text { Nornicotine concentration } \\
{[\mathrm{ng} / \mathrm{mL}]}\end{array}$} & $\mathrm{CTRL}$ & $1255.23^{\mathrm{b}, \mathrm{c}, \mathrm{d}}$ & $2890.93^{\mathrm{b}, \mathrm{c}, \mathrm{d}}$ & $1141.81^{\mathrm{b}, \mathrm{d}}$ & $1842.12^{\mathrm{b}, \mathrm{c}, \mathrm{d}}$ \\
\cline { 2 - 6 } & 0.08 & $1052.17^{\mathrm{a}}$ & 2593.27 & $746.60^{\mathrm{a}, \mathrm{c}, \mathrm{d}}$ & $1254.51^{\mathrm{a}, \mathrm{c}, \mathrm{d}}$ \\
\cline { 2 - 6 } & 0.12 & $1094.66^{\mathrm{a}, \mathrm{d}}$ & 2554.90 & $1059.78^{\mathrm{b}, \mathrm{d}}$ & $1711.52^{\mathrm{a}, \mathrm{b}, \mathrm{d}}$ \\
\cline { 2 - 6 } & 0.16 & $925.21^{\mathrm{a}, \mathrm{c}}$ & 2448.92 & $880.21^{\mathrm{a}, \mathrm{b}, \mathrm{c}}$ & $1475.97^{\mathrm{a}, \mathrm{b}, \mathrm{c}}$ \\
\hline
\end{tabular}

${ }^{\mathrm{a}-\mathrm{d}}$ statistically significant differences ( $\mathrm{P}<0.05$; Mann-Whitney $U$-test); ${ }^{\mathrm{a}} v$. CTRL; ${ }^{\mathrm{b}} v s .0 .08 \mathrm{ng} / \mathrm{mL}$ nornicotine; ${ }^{c} v s .0 .12 \mathrm{ng} / \mathrm{mL}$ nornicotine; ${ }^{\mathrm{d}} v s .0 .16 \mathrm{ng} / \mathrm{mL}$ nornicotine. CTRL — control

Analysis of the fluorescence intensity of F-actin measured in whole EA.hy926 cells in the focal plane of junctional ZO-1 showed a statistically significant decrease following treatment of the cells with 0.08 and $0.16 \mathrm{ng} / \mathrm{mL}$ nornicotine, compared to the control $(\mathrm{P}<0.0001$ and $\mathrm{P}=0.0002$, respectively). Comparison of the control cells with the cells treated with $0.12 \mathrm{ng} / \mathrm{mL}$ nornicotine did not reveal any statistically significant difference. However, statistically significant differences were seen between cells treated with 0.08 and $0.12 \mathrm{ng} / \mathrm{mL}$ $(\mathrm{P}<0.0001)$, between 0.08 and $0.16 \mathrm{ng} / \mathrm{mL}$ $(P=0.0101)$, and between 0.12 and $0.16 \mathrm{ng} / \mathrm{mL}$ nornicotine $(\mathrm{P}=0.0009)$ (Figure $7 \mathrm{C}$, Table 2$)$. 


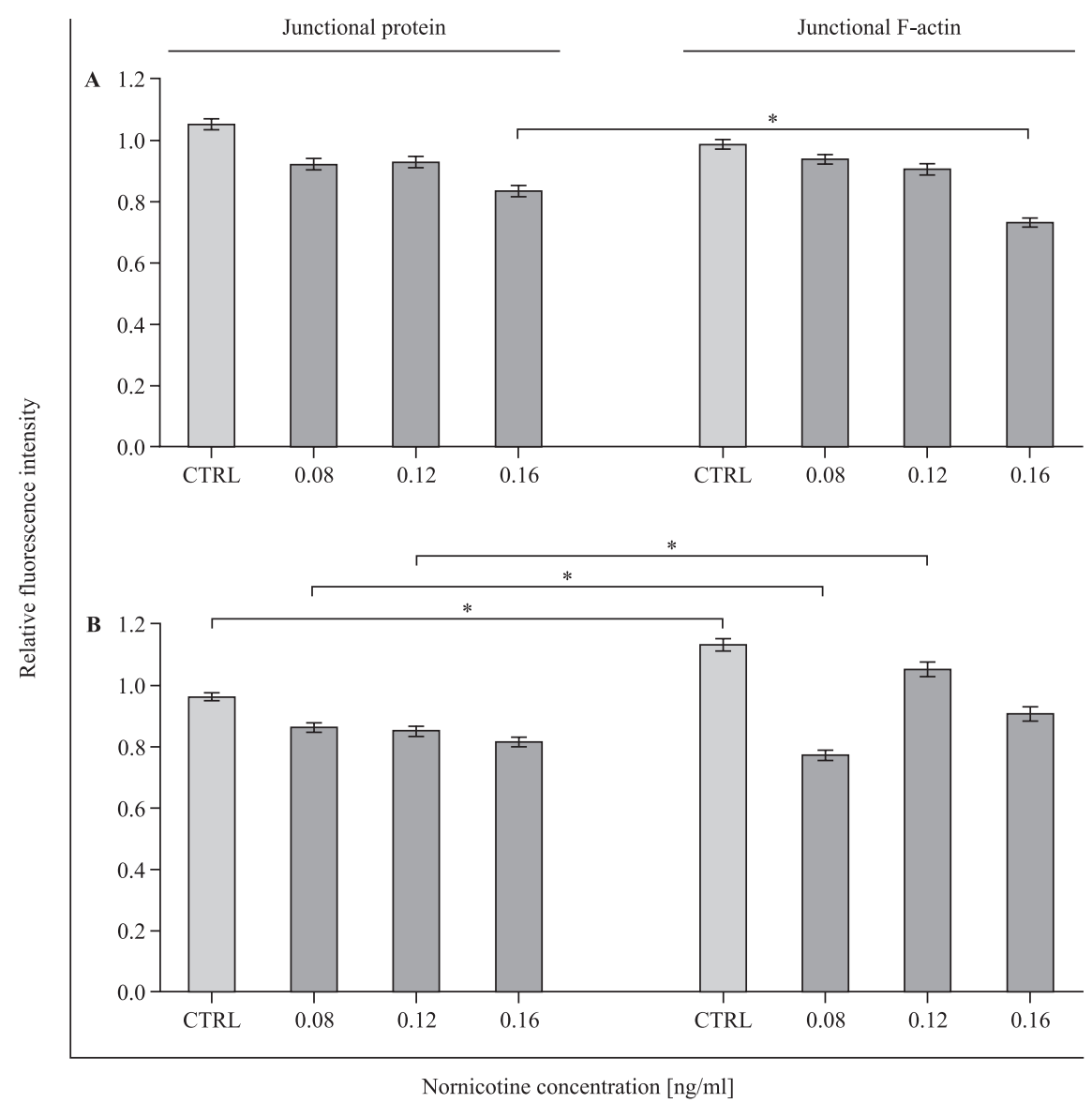

Figure 8. Effect of nornicotine on the relative fluorescence intensity of junctional beta-catenin/F-actin and junctional ZO-1/F-actin. EA.hy926 cells were treated with $0.08,0.12$, and $0.16 \mathrm{ng} / \mathrm{mL}$ nornicotine for $24 \mathrm{~h}$ and examined by confocal microscopy. Images were captured in the focal plane of junctional proteins. The analysis of fluorescence intensity of beta-catenin/F-actin and ZO-1/F-actin was performed on confocal images for whole cells and cell-cell interaction areas. The relative fluorescence values were calculated by dividing the fluorescence intensity values measured in the cell-cell interaction areas by the medians of the fluorescence intensities measured in the cell-cell interaction areas of the control cells. *Statistically significant differences; P $<0.05$; Mann-Whitney $U$-test. (A) Relative fluorescence intensity of junctional beta-catenin and F-actin measured in EA.hy926 cells treated with nornicotine; (B) Relative fluorescence intensity of junctional ZO-1 and F-actin measured in EA.hy926 cells treated with nornicotine. CTRL — control

The measurement of fluorescence intensity of $\mathrm{F}$-actin in cell-cell interaction areas showed a similar arrangement of columns on graph. However, statistically significant differences between all compared groups were seen, and the values of fluorescence intensity were 1.61-1.68 times higher (Figure $7 \mathrm{D}$, Table 2).

\section{Analysis of relative fluorescence changes in junctional beta-catenin, ZO-1, and colocalized F-actin in EA.hy926 cells treated with nornicotine}

The effect of nornicotine on the relative fluorescence changes in junctional beta-catenin, ZO-1, and the F-actin colocalized with them in EA.hy926 cells cultured with and without exposure to $0.08,0.12$, or 0.16 $\mathrm{ng} / \mathrm{mL}$ nornicotine was investigated with the use of a laser scanning confocal microscope. The images were acquired in confocal mode in the focal plane of the junctional proteins. The relative fluorescence values of the junctional proteins were calculated by dividing the fluorescence intensity values measured in cell-cell interaction areas by the medians of the fluorescent intensities measured in cell-cell interaction areas of the control.

Analysis of the relative fluorescence of junctional beta-catenin and colocalized F-actin showed a statistically significant decrease only as compared with values from cells treated with $0.16 \mathrm{ng} / \mathrm{mL}$ nornicotine (from 0.83 to $0.73, \mathrm{P}=0.0002$ after comparison of relative fluorescence intensity values of junctional beta-catenin and colocalized F-actin). The comparison between 
the relative fluorescent intensity values of junctional beta-catenin and colocalized F-actin, as measured in the control and in cells treated with 0.08 or $0.12 \mathrm{ng} / \mathrm{mL}$ nornicotine, did not show any statistically significant differences $(\mathrm{P}=0.1710, \mathrm{P}=0.0672, \mathrm{P}=0.8890$ for the control and for cells treated with 0.08 or $0.12 \mathrm{ng} /$ $\mathrm{mL}$ nornicotine, respectively) (Figure $8 \mathrm{~A}$ ).

Unlike the results obtained for the comparison of junctional beta-catenin and colocalized F-actin, the analysis of the relative fluorescence intensity of junctional ZO-1 and colocalized F-actin showed statistically significant differences between the controls (increase from 0.96 to $1.13 ; \mathrm{P}=0.0034$ ), the cells treated with $0.08 \mathrm{ng} / \mathrm{mL}$ nornicotine (decrease from 0.86 to $0.77 ; \mathrm{P}<0.0001$ ), and those treated with $0.12 \mathrm{ng} / \mathrm{mL}$ (increase from 0.85 to $1.05 ; \mathrm{P}<0.0001$ ). Comparison of the relative fluorescence intensity values of ZO-1 and the colocalized F-actin in cells cultured in the presence of nornicotine at a concentration of $0.16 \mathrm{ng} / \mathrm{mL}$ showed that the differences were statistically insignificant $(\mathrm{P}=0.1569)$ (Figure $8 \mathrm{~B}$ ).

\section{Discussion}

The relation between tobacco smoking and the probability of atherosclerosis and cardiovascular disease has been clearly demonstrated in a number of epidemiological studies [29-31]. However, knowledge of nicotine metabolites is poor, especially in relation to cell-cell junctions.

In the present study, EA.hy926 cells were treated with $0.08,0.12$, and $0.16 \mathrm{ng} / \mathrm{mL}$ nornicotine, and no statistically significant differences were seen in the percentages of live, early-apoptotic, late-apoptotic, and necrotic cells. On the other hand, as has been shown by Kratzer et al. and our own data (unpublished), the treatment of cells with cigarette smoke extract (CSE) in both HUVECs and EA.hy926 cell line induces dose-dependent cell death [32]. However, it has been pointed out that CSE induces necrotic cell death in HUVEC cells. Yet In our unpublished studies, 24 h treatment of EA.hy926 cells with $25 \%$ and $50 \%$ CSE prepared from burning three cigarettes per $10 \mathrm{ml}$ culture medium induced mostly early apoptosis (unpublished data). An in vivo increase in cell death frequency was observed by Lin et al. following treatment of rats with nicotine [33].

Although our study did not reveal any alteration in EA.hy926 cell line survival following treatment of such cells with nornicotine, various effects were produced in terms of cell mobility, and changes in the organization of both cell-cell junctional complexes and F-actin occurred. The results of the present study show that all doses of nornicotine increase the migratory po- tential of EA.hy926 cells in a statistically significant way, compared with the control. Similarly, Park et al. have shown that nicotine stimulates cell proliferation, migration, and tube formation in HUVECs at concentrations similar to those found in smokers [34]. Moreover, the cell migratory experiments performed in the present work correlate with the number of Weibel-Palade bodies seen via TEM. The Weibel -Palade bodies include vascular endothelial growth factor (VEGF), whose isoforms regulate a variety of vascular processes, including angiogenesis, vascular permeability, and vasodilation [35-37]. The present study demonstrates that, together with an increase of Weibel-Palade bodies, the migratory potential was lower. Conklin et al. have demonstrated that nicotine and cotinine cause a significant increase in endothelial cell VEGF expression. They additionally suggested that this may have important implications in vascular disease by increasing the endothelial turnover and the permeability to atherogenic macromolecules, such as low-density lipoprotein (LDL), as well as by increasing tumor growth and metastasis via increased angiogenesis [38]. We suggest that the decrease in the number of Weibel-Palade bodies in EA.hy926 cells treated with 0.08 and $0.16 \mathrm{ng} / \mathrm{mL}$ nornicotine is caused by the depolymerization of F-actin, which was clearly visible in the focal plane of ZO-1, which also indicates that the promotion of cell movement after nornicotine treatment is VEGF-independent. Many other studies have also shown that actin depolymerization inhibits exocytosis [39-43].

Additionally, we have previously reported that ZO-1, similarly to beta-catenin, may bind to F-actin directly and stabilize the endothelial barrier function via stabilization of F-actin after treatment of EA.hy926 cell with L-homocysteine [44]. However, the present work revealed the lack of dependence between the decrease in F-actin fluorescence intensity and the $\mathrm{ZO}-1$ protein. We suggest that the correlation of ZO-1 and F-actin stabilization depends mostly on the type of stimulus and on the organizational changes in F-actin induced by different factors. Moreover, the results of the measurement of beta-catenin and F-actin fluorescence intensity confirmed that the actin cytoskeleton plays an important role in the maintenance of endothelial AJs.

Furthermore, in the present study, the treatment of EA.hy926 cells with nornicotine resulted in increases in extracellular spaces, as a consequence of the loss of cell-cell contact. It has been suggested by Sandig et al. that the transmigration of monocytes through circular openings is limited by F-actin and partially by alpha-catenin, resulting in monocyte accumulation in atherosclerotic plaques [12]. We suggest 
here that nornicotine may assist in the formation of transmigration passages, formed by pseudopodia of monocytes, and in consequence in their penetration between adjacent endothelial cells.

In conclusion, the present study demonstrates that low concentrations of nornicotine does not affect cell survival, but does induce promotion of cell movement and does impair AJs through changes in F-actin organization. Moreover, the data presented in this study suggest that the mechanism of cell migration promotion is VEGF-independent and that the decrease in the number of Weibel-Palade bodies is the effect of nornicotine-induced F-actin depolymerization. Our results for the first time indicate the effect of nornicotine on endothelial EA.hy926 cells - especially in the context of its role in the dysfunction of cell-cell junctions - and may suggest that nornicotine induces transmigration passages and consequently facilitates the transmigration of monocytes associated with atherosclerosis.

\section{Acknowledgement}

This study was supported by the Polish National Science Center (NCN) grant N N401 596140.

\section{References}

1. Saarikangas J, Zhao H, Lappalainen P. Regulation of the actin cytoskeleton-plasma membrane interplay by phosphoinositides. Physiol Rev. 2010;90:259-289.

2. Zhang J, Betson M, Erasmus J et al. Actin at cell-cell junctions is composed of two dynamic and functional populations. J Cell Sci. 2005;118:5549-5562.

3. Dejana E. Endothelial cell-cell junctions: happy together. Nat Rev Mol Cell Biol. 2004;5:261-270.

4. Harris ES, Nelson WJ. VE-cadherin: at the front, center, and sides of endothelial cell organization and function. Curr Opin Cell Biol. 2010;22:651-658.

5. Harris TJ, Tepass U. Adherens junctions: from molecules to morphogenesis. Nat Rev Mol Cell Biol. 2010;11:502-514.

6. Yonemura S. Cadherin-actin interactions at adherens junctions. Curr Opin Cell Biol. 2011;23:515-522.

7. Bazzoni G, Martínez Estrada O, Dejana E. Molecular structure and functional role of vascular tight junctions. Trends Cardiovasc Med. 1999;9:147-152.

8. Braga VM. Cell-cell adhesion and signalling. Curr Opin Cell Biol. 2002;14:546-556.

9. Matter K, Balda MS. Signalling to and from tight junctions. Nat Rev Mol Cell Biol. 2003;4:225-236.

10. Wheelock MJ, Johnson KR. Cadherin-mediated cellular signaling. Curr Opin Cell Biol. 2003;15:509-514.

11. Hoelzle MK, Svitkina T. The cytoskeletal mechanisms of cell-cell junction formation in endothelial cells. Mol Biol Cell. 2012;23:310-323.

12. Sandig M, Korvemaker ML, Ionescu CV et al. Transendothelial migration of monocytes in rat aorta: distribution of F-actin, alpha-catnin, LFA-1, and PECAM-1. Biotech Histochem. 1999;74:276-293.

13. Mine S, Tabata T, Wada Y et al. Oxidized low density lipoprotein-induced LFA-1-dependent adhesion and transen- dothelial migration of monocytes via the protein kinase $\mathrm{C}$ pathway. Atherosclerosis. 2002;160:281-288.

14. Homeister, JW, Willis MS. Atherosclerosis: Pathogenesis, Genetics and Experimental Models. In: encyclopedia of life sciences 2010, John Wiley \& Sons, Ltd: Chichester; http:// //www.els.net/ DOI: 10.1002/9780470015902.a0005998.pub2.

15. Burns DM. Cigarettes and cigarette smoking. Clin Chest Med. 1991;12:631-642.

16. Bernhard D, Moser C, Backovic A, Wick G. Cigarette smoke -an aging accelerator? Exp Gerontol. 2007;42:160-165.

17. Bernhard D, Wick $G$. In vitro models for the analysis of cigarette smoke effects. In: Wang, X., Scott, D. (Eds.), Molecular Mechanisms of Tobacco-induced Diseases. Nova Science: New York; 2006:29-54.

18. Schweitzer KS, Hatoum H, Brown MB et al. Mechanisms of lung endothelial barrier disruption induced by cigarette smoke: role of oxidative stress and ceramides. Am J Physiol Lung Cell Mol Physiol. 2011;301:L836-846.

19. Lu Y, Ward SC, Cederbaum AI. Nicotine enhances ethanol -induced fat accumulation and collagen deposition but not inflammation in mouse liver. Alcohol. 2013;47:353-357.

20. Siminszky B, Gavilano L, Bowen SW et al. Conversion of nicotine to nornicotine in Nicotiana tabacum is mediated by CYP82E4, a cytochrome P450 monooxygenase. Proc Natl Acad Sci U S A. 2005;11:14919-14924.

21. Jacob P, Yu L, Shulgin AT et al. Minor tobacco alkaloids as biomarkers for tobacco use: comparison of users of cigarettes, smokeless tobacco, cigars, and pipes. Am J Public Health. 1999;89:731-736.

22. Breen LT, McHugh PE, Murphy BP. HUVEC ICAM-1 and VCAM-1 synthesis in response to potentially athero-prone and athero-protective mechanical and nicotine chemical stimuli. Ann Biomed Eng. 2010;38:1880-1892.

23. Pena VB, Bonini IC, Antollini SS et al. Alpha 7-type acetylcholine receptor localization and its modulation by nicotine and cholesterol in vascular endothelial cells. J Cell Biochem. 2011;112:3276-3288.

24. Romani F, Lanzone A, Tropea A et al. Nicotine_and cotinine affect the release of vasoactive factors by trophoblast cells and human umbilical vein endothelial cells. Placenta. 2011;32:153-160.

25. Kathuria S, Mahadevan N, Balakumar P. Possible involvement of PPAR $\gamma$-associated eNOS signaling activation in rosuvastatin-mediated prevention of nicotine-induced experimental vascular endothelial abnormalities. Mol Cell Biochem. 2013;374:61-72.

26. Wernsman EA, Matzinger DF. Time and site of nicotine conversion in tobacco. Tob Sci. 1968;12:226-228.

27. Williams DE, Shigenaga MK, Castagnoli N Jr. The role of cytochromes P-450 and flavin-containing monooxygenase in the metabolism of (S)-nicotine by rabbit lung. Drug Metab Dispos. 1990;18:418-428.

28. Dwoskin LP, Crooks PA, Teng L et al. Acute and chronic effects of nornicotine on locomotor activity in rats: altered response to nicotine. Psychopharmacology (Berl). 1999;145:442-451.

29. Panagiotakos DB, Pitsavos Ch, Chrysohoou Ch et al. The role of traditional mediterranean type of diet and lifestyle, in the development of acute coronary syndromes: preliminary results from CARDIO 2000 study. Cent Eur J Public Health. 2002;10:11-15.

30. Baggio B, Budakovic A, Perissinotto E et al. ILSA Working Group. Atherosclerotic risk factors and renal function in the elderly: the role of hyperfibrinogenaemia and smoking. Results from the Italian Longitudinal Study on Ageing (ILSA). Nephrol Dial Transplant. 2005;20:114-123. 
31. Barnoya J, Glantz SA. Cardiovascular effects of secondhand smoke: nearly as large as smoking. Circulation 2005; 111:2684-2698. 32. Kratzer E, Tian Y, Sarich N et al. Oxidative stress contributes to lung injury and barrier dysfunction via microtubule destabilization. Am J Respir Cell Mol Biol. 2012;47:688-697.

33. Lin SJ, Hong CY, Chang MS et al. Long-term nicotine exposure increases aortic endothelial cell death and enhances transendothelial macromolecular transport in rats. Arterioscler Thromb. 1992;12:1305-1312.

34. Park YJ, Lee T, Ha $\mathbf{J}$ et al. Effect of nicotine on human umbilical vein endothelial cells (HUVECs) migration and angiogenesis. Vascul Pharmacol. 2008;49:32-36.

35. Lakier JB. Smoking and cardiovascular disease. Am J Med. 1992;93:8S-12S

36. Bartecchi CE, MacKenzie TD, Schrier RE. The human costs of tobacco use. N Engl J Med. 1994;330:907-912.

37. Powell JT. Vascular damage from smoking: disease mechanism at the arterial wall. Vasc Med. 1998;3:21-28.

38. Conklin BS, Zhao W, Zhong DS et al. Nicotine and cotinine up-regulate vascular endothelial growth factor expression in endothelial cells. Am J Pathol. 2002;160:413-418.
39. Lang T, Wacker I, Wunderlich I et al. Role of actin cortex in the subplasmalemmal transport of secretory granules in PC-12 cells. Biophys J. 2000;78:2863-2877.

40. Jahraus A, Egeberg M, Hinner B et al. ATP-dependent membrane assembly of F-actin facilitates membrane fusion. Mol Biol Cell 2001;12:155-170.

41. Eitzen G, Wang L, Thorngren $\mathrm{N}$ et al. Remodeling of organelle-bound actin is required for yeast vacuole fusion. $J$ Cell Biol. 2002;158:669-679.

42. Gasman S, Chasserot-Golaz S, Malacombe Met al. Regulated exocytosis in neuroendocrine cells: a role for subplasmalemmal Cdc42/N-WASP-induced actin filaments. Mol Biol Cell. 2004;15:520-531.

43. Malacombe M, Bader MF, Gasman S. Exocytosis in neuroendocrine cells: new tasks for actin. Biochim Biophys Acta 2006; 1763:1175-1183.

44. Gagat M, Grzanka D, Izdebska M et al. Effect of L-homocysteine on endothelial cell-cell junctions following F-actin stabilization through tropomyosin-1 overexpression. Int J Mol Med. 2013;32:115-129.

Submitted: 15 June, 2013

Accepted after reviews: 27 September, 2013 